\title{
Leachate Quality Characteristics: A Case Study of Two Industrial Solid Waste Dumpsites
}

\author{
Effiong Ukorebi Etim*, Percy Chuks Onianwa
}

Department of Chemistry, University of Ibadan, Ibadan, Nigeria.

Email: *etim242@yahoo.com

Received February $26^{\text {th }}, 2013$; revised March $29^{\text {th }}, 2013$; accepted April $28^{\text {th }}, 2013$

Copyright @ 2013 Effiong Ukorebi Etim, Percy Chuks Onianwa. This is an open access article distributed under the Creative Commons Attribution License, which permits unrestricted use, distribution, and reproduction in any medium, provided the original work is properly cited.

\begin{abstract}
The study evaluates the associated environmental risk of two industrial solid waste dumpsites. The Toxicity Characteristic Leaching Procedure (TCLP) and American Society for Testing and Materials (ASTM) extraction test were used to characterize leachate quality on six solid waste samples obtained in July 2005, March 2006 and July 2006. Solid waste compositions varied with $58 \%$ metal scraps, $30 \%$ vegetation matter, $10 \%$ plastics and $2 \%$ paper materials. Statistical T-test (95\% confidence limit) showed no significance difference in physico-chemical quality of the leachates obtained by both methods from both sites. Leachates obtained by the TCLP extraction accounted for a total of $92.4 \%$ of the overall metal load as against $6.01 \%$ for the ASTM method. This disparity is due to the acidic nature of the TCLP procedure which enhances more efficient extraction of metals than the ASTM method. Solid waste deposits at SITE-1 were considered hazardous to the environment, given that the upper 90\% UCL values for lead exceeded the TCLP characteristic regulatory levels. These may pose a risk to vegetations and ground water reserve within the vicinity of the dumpsite on the long run. The risk may be such as bioaccumulation of lead in the food chain. Therefore, constant monitoring and possible remediation measures should be carried out to contained contamination.
\end{abstract}

Keywords: Leachate; Solid Waste; Dumpsite; Lead; Waste Management

\section{Introduction}

The contamination of the natural environment from heavy metals leaching from hazardous solid waste stock piles constitutes a global problem. Most common hazardous solid wastes comprise both complex industrial and municipal waste systems, which are mostly disposed off on poorly constructed and managed dumpsites. The Leachate generated from such containment sites is known to contain many complex organic and inorganic pollutants [1]. These pollutants from industrial solid waste stock piles have been identified as one of the major threats to the environment [2,3] and have given rise to a number of studies in recent years [4-7]. Decisions made regarding the appropriate waste management options of industrial solids waste frequently rely on an assessment of risk. One of the key pathways when evaluating the risk of an industrial solid waste on human health and the environment is leaching of pollutants to ground water reserve [8]. In order to evaluate the leaching risk, many

\footnotetext{
${ }^{*}$ Corresponding author.
}

leaching tests have been developed and are widely used under a vast range of waste management scenarios [9]. The United State Environmental Protection Agency (USEPA) Toxicity Characteristic Leaching Procedure (TCLP), American Society of Testing and Materials (ASTM), Synthetic Precipitation Leaching Procedure (SPLP), among others risk leaching test $[10,11]$ have been used to assess the mobility of toxic metals released from solid waste sites. The TCLP test, widely used by state and national agencies, was designed to simulate leaching of heavy metals and organics from industrial wastes to be co-disposed in municipal solid waste landfills.

In Nigerian, the gains of the industrial revolution have also brought with it the attendant environmental problems. Indiscriminate disposal of industrial solid waste at poorly constructed and managed dumpsites is common. Two of such sites are within the Ota industrial estate in southwestern region of Nigeria. There are about $48 \%$ metal-base industries within the estate. Industrial solid waste stock piles within the sites and seepage of leachates from solid waste have the potential of contami- 
nating ground water reserves. For this study, two batch leaching extraction test protocols were used to evaluate the solid waste leaching potentials of pollutants in the solid waste under specific environmental conditions, and thus evaluated potential risk to humans and/or ground water supply. A comparative study was equally carried out between the two methods, and results also compared with standards to determine the hazardous nature of the solid waste.

\section{Materials and Method}

\subsection{Sampling Design}

Two solid waste dumpsites were identified within the industrial estate for sample collection. Five solid waste samples were pulled from each site to give a representative composite sample. The sampling was carried for a period of three months (July 2005, March 2006 and July 2006). A total of six composite samples were collected in all. Samples were scoped with a plastic trowel into and stored in polythene bags. After collection, the samples were air dried in a clean room in the laboratory to remove moisture. The dried solid waste samples were sorted/characterized and ground using mechanical grinder. Two batch procedures adopted by the United State Environmental Protection Agency, the Toxicity Characteristic Leaching Procedure (TCLP) and the American Society for Testing and Materials (ASTM) were used for simulating leachates from the solid waste samples $[9,12]$.

\subsection{Chemical Analysis}

\subsubsection{US-EPA TCLP Extraction Procedure}

A $50.0 \mathrm{~g}$ of solid waste sample was placed in a one liter glass bottle containing $800 \mathrm{~mL}$ water, (i.e. a liquid to solid (L/S) ratio of 16:1). The mixture was placed on a mechanical shaker and agitated for 24 hours. During the extraction, the $\mathrm{pH}$ was adjusted and held between 4.8 and 5.2 by addition of $0.5 \mathrm{~N}$ acetic acid, or until a maximum of $4 \mathrm{~mL}$ of acid per gram of sample was added. After 24 hours, the liquid volume was adjusted to $1000 \mathrm{~mL}$ by the addition of $200 \mathrm{~mL}$ of water, i.e. 20 times the weight of the solid. The extract was separated by filtration through a filter paper into a one liter plastic bottle for analysis.

\subsubsection{ASTM Extraction Procedure}

A $1000 \mathrm{~mL}$ of water was added to $250 \mathrm{~g}$ of solid waste sample in a one liter glass bottle (i.e. a liquid to solid ratio of $4: 1$ ). The waste mixture was placed on a reciprocating platform shaker for $48 \pm 0.5$ hours at room temperature. No $\mathrm{pH}$ adjustment was used in the ASTM Method. After 48 hours the solid and liquid portions were separated by filtration. The extracts were stored in one-liter plastic bottles for analysis.
The leachate extracts were analyzed for $\mathrm{pH}$, alkalinity, chloride, total hardness, calcium, magnesium, dissolved solids, sulphate, ammonia, nitrate, phosphate and heavy metals $(\mathrm{Pb}, \mathrm{Cd}, \mathrm{Cr}, \mathrm{Co}, \mathrm{Cu}$, and $\mathrm{Ni}$ ) using standard procedure of Hanson [13] and APHA AWWA-WPCE [14]. A blank sample was incorporated for the extraction and analysis. The filtrates were analyzed for lead, cadmium, chromium, cobalt, copper and nickel using an atomic absorption spectrophotometer (Buck Scientific, model 200A).

\section{Results and Discussion}

\subsection{Characterization of Solid Waste}

Characterization of solid waste from the two dumpsites showed compositions to vary with $58 \%$ metal scraps, $30 \%$ vegetation matter, $10 \%$ plastics and $2 \%$ paper materials. These sites are mostly used by industrial facilities within the estate. The high load of metal scraps (58\%) may be attributed to the dumping of lead ingot, aluminum scraps, plastic chips, copper and steel scraps at this location by industries. The composition of these wastes reflects the nature of industrial facilities that are operational at the Ota estate (mostly non-ferrous and ferrous metal based).

\subsection{Characterization of Leachate Quality}

Acidic $\mathrm{pH}$ values (4.9 and 5.03) were generally obtained from leachates by the TCLP procedure (Table 1). These low $\mathrm{pH}$ value may enhance the mineralization of solid waste, which is evident with slightly higher total hardness, calcium and dissolved solids from the leachates compared with that obtained from the ASTM method. Statistical T-test (95\% confidence limit) showed no significance difference in physico-chemical quality of the leachates obtained by both methods from both sites. The ASTM extraction method evaluates the release of pollutant constituents under conditions similar to those within a segregated landfill. The average levels of $\mathrm{Pb}, \mathrm{Cu}$ and $\mathrm{Ni}$ by this method were higher in leachates obtained from SITE-2 compared to SITE-1. These levels however, may not be of environmental significance. The TCLP extraction test method evaluates the potential of an industrial waste to release metal and organic constituents from a waste site [9]. Average $\mathrm{Pb}, \mathrm{Cu}$ and $\mathrm{Ni}$ levels by this method were however higher in leachates obtained from SITE-1. Large deposit of lead ingot, aluminum scraps, plastic chips, copper and steel scraps may account for the likely source of high $\mathrm{Pb}, \mathrm{Cu}$ and $\mathrm{Ni}$ levels at SITE-1. Leachates simulated from SITE-1 and SITE-2 by both extraction methods had no appreciable levels of $\mathrm{Pb}, \mathrm{Cr}$, and $\mathrm{Cd}$ when compared with Toxicity Characteristic Leaching Procedure (TCLP) regulatory limits. Statistical T-test (95\% confidence limit) showed significant differences in metal levels between the containment sites 
Table 1. Average leachates quality from the two dumpsites.

\begin{tabular}{|c|c|c|c|c|c|}
\hline \multirow{2}{*}{ Parameter } & \multicolumn{2}{|c|}{ SITE-1 } & \multicolumn{2}{|c|}{ SITE-2 } & \multirow{2}{*}{$\begin{array}{l}\text { TCLP Characteristic } \\
\text { Regulatory Levels }\end{array}$} \\
\hline & ASTM & TCLP & ASTM & TCLP & \\
\hline $\mathrm{pH}$ & $7.20 \pm 0.17$ & $4.9 \pm 1.6$ & $7.67 \pm 0.90$ & $5.03 \pm 0.40$ & - \\
\hline Alkalinity & $147 \pm 51$ & $135 \pm 150$ & $159 \pm 33$ & $281 \pm 290$ & - \\
\hline Chloride & $5.4 \pm 7.6$ & $95 \pm 160$ & $17.9 \pm 7.4$ & $22 \pm 20$ & - \\
\hline Total hardness & $80 \pm 34$ & $355 \pm 100$ & $125 \pm 10$ & $380 \pm 140$ & - \\
\hline Calcium & $26 \pm 11$ & $110 \pm 26$ & $28.7 \pm 9.3$ & $107 \pm 53$ & - \\
\hline Magnesium & $3.5 \pm 1.8$ & $19.5 \pm 9.3$ & $12.7 \pm 7.7$ & $26.7 \pm 1.6$ & - \\
\hline Dissolved Solids & $239 \pm 79$ & $788 \pm 300$ & $208 \pm 54$ & $484 \pm 170$ & - \\
\hline Sulphate & $21 \pm 26$ & $28 \pm 27$ & $52 \pm 26$ & $38 \pm 20$ & - \\
\hline Ammonia & $0.8 \pm 1.1$ & $0.16 \pm 0.07$ & $0.21 \pm 0.13$ & $0.16 \pm 0.06$ & - \\
\hline Nitrate & $0.88 \pm 0.19$ & $0.47 \pm 0.19$ & $1.47 \pm 0.56$ & $0.62 \pm 0.09$ & - \\
\hline Phosphate & $0.04 \pm 0.01$ & $0.08 \pm 0.06$ & $0.09 \pm 0.05$ & $0.07 \pm 0.04$ & - \\
\hline Lead & $27 \pm 26$ & $2250 \pm 3400$ & $201 \pm 200$ & $32 \pm 51$ & 5000 \\
\hline Chromium & $28 \pm 30$ & $323 \pm 110$ & $1.7 \pm 2.8$ & $190 \pm 86$ & 5000 \\
\hline Copper & $152 \pm 200$ & $848 \pm 520$ & $232 \pm 83$ & $296 \pm 99$ & - \\
\hline Cobalt & $18 \pm 6$ & $148 \pm 50$ & $16.3 \pm 7.6$ & $103 \pm 66$ & - \\
\hline Cadmium & $13 \pm 13$ & $104 \pm 39$ & $46 \pm 16$ & $51.7 \pm 30$ & 1000 \\
\hline Nickel & $39 \pm 12$ & $538 \pm 230$ & $123 \pm 46$ & $283 \pm 150$ & - \\
\hline
\end{tabular}

Leachate metal concentrations in $\mu \mathrm{g} / \mathrm{L}$, other parameters in $\mathrm{mg} / \mathrm{L}, \mathrm{pH}$ has no unit. ASTM-American Society for Testing and Materials, TLCP-Toxicity Characteristic Leaching Procedure

for the TCLP method. From the principal component biplot (Figure 1), the point to the left (SITE-1/ASTM and SITE-2/ASTM) of the origin had lower concentrations of metals than points on the right (SITE-1/TCLP and SITE-2/TCLP). The TCLP method accounts for a total of $92.4 \%$ (component 1 ) of the overall metal load at the dumpsites as against $6.01 \%$ (component 2) for the ASTM method from both sites. The acidic nature of the TCLP procedure enhances more efficient extraction of metals than the ASTM method. This may explain why metal concentrations in TCLP leachates are slightly higher than extracts from ASTM procedure. This trend was also observed from the cluster analysis dendrogram of Figure 2. A strong positive correlation ( $p=0.05$ ) was observed for metals between the two methods at both sites (Table 2). Correspondence analysis showed pollutants in order of $\mathrm{Pb}>\mathrm{Cu}>\mathrm{Ni}>\mathrm{Cd}>\mathrm{Cr}>\mathrm{Co}$ at both dumpsites. Average $\mathrm{Pb}$ and $\mathrm{Cd}$ levels, dissolved solids and total hardness obtained from the two methods were far lower than $10.2 \mathrm{mg} / \mathrm{L}, 8.80 \mathrm{mg} / \mathrm{L}, 62,000 \mathrm{mg} / \mathrm{L}$ and 93,000 $\mathrm{mg} / \mathrm{L}$ respectively reported for leachates in unlined MSW landfill in Igando New Town in Lagos metropolis [7]. Meanwhile, $\mathrm{Pb}, \mathrm{Cr}, \mathrm{Cu}, \mathrm{Cd}$ and $\mathrm{Ni}$ levels in this study were about levels reported in a MSW landfill in India [8].

For replicate $(n=3)$ leaching tests, coefficients of variation (CV) of up to $100 \%$ were frequently obtained (Table 3). On the risk assessment of the dump site, US-EPA waste management criteria suggests that for management of waste as non hazardous, the upper confidence limit (UCL) should be below the regulatory standard using $90 \%$ confidence criteria [15]. Based on this, the solid waste at SITE-1 could be considered hazardous to the environment, given that the upper $90 \%$ UCL values for $\mathrm{Pb}$ exceeded the TCLP characteristic regulatory levels. These may pose risk to ground water reserve within the vicinity of the dumpsite and the entire estate on the long run.

In conclusion, the TCLP extraction method had slightly high pollutant levels. Industrial solid waste found within SITE-1 was found to be contaminated with $\mathrm{Pb}$. Of particular interest is that solid waste at SITE-1 would therefore be considered hazardous to the environment and may pose risk to ground water quality. Vegetations around the dumpsite may similarly be contaminated with $\mathrm{Pb}$ thereby affecting grazing animals and wild life. 


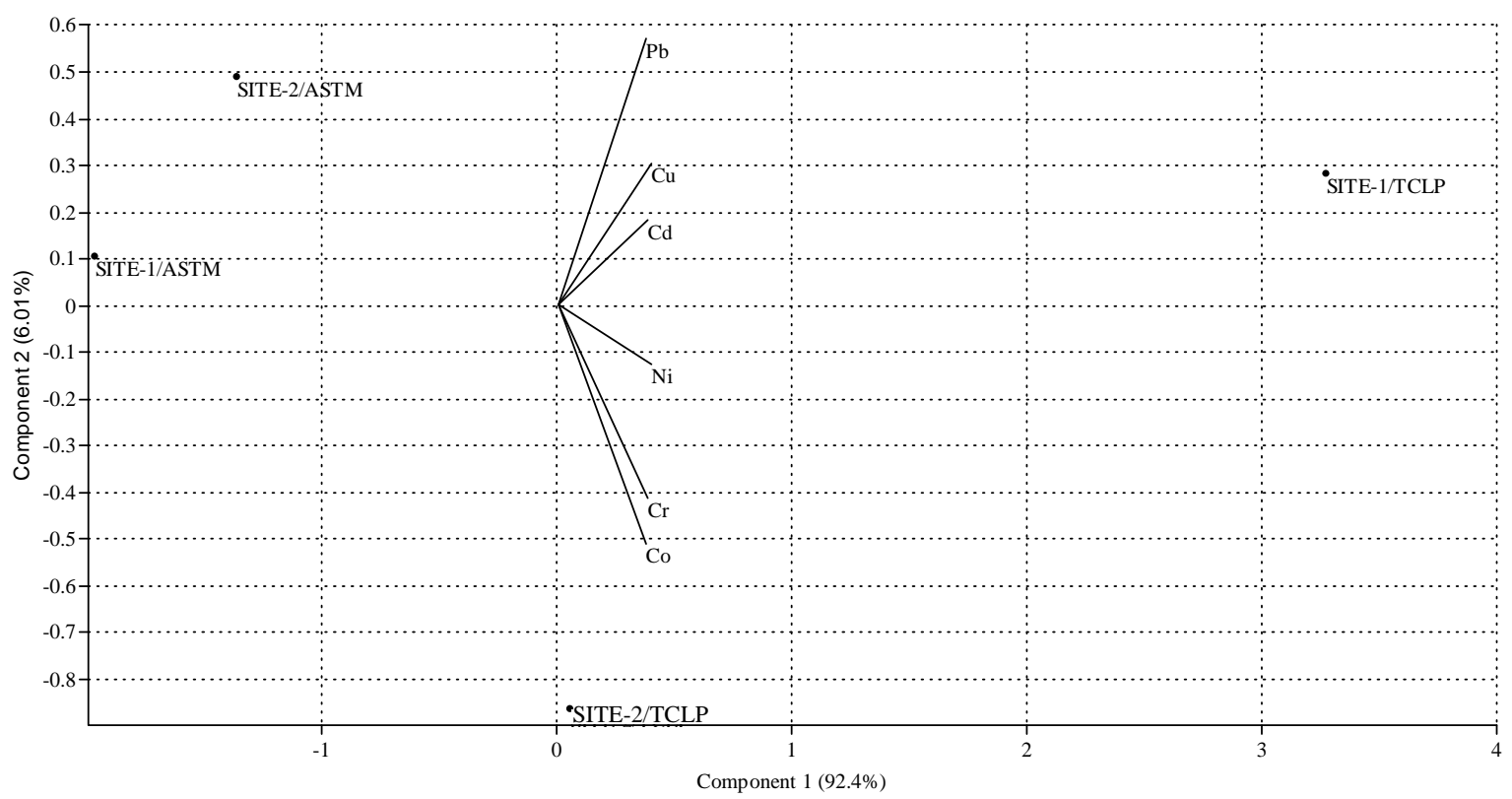

Figure 1. Principal component biplot of leachate metal data set.

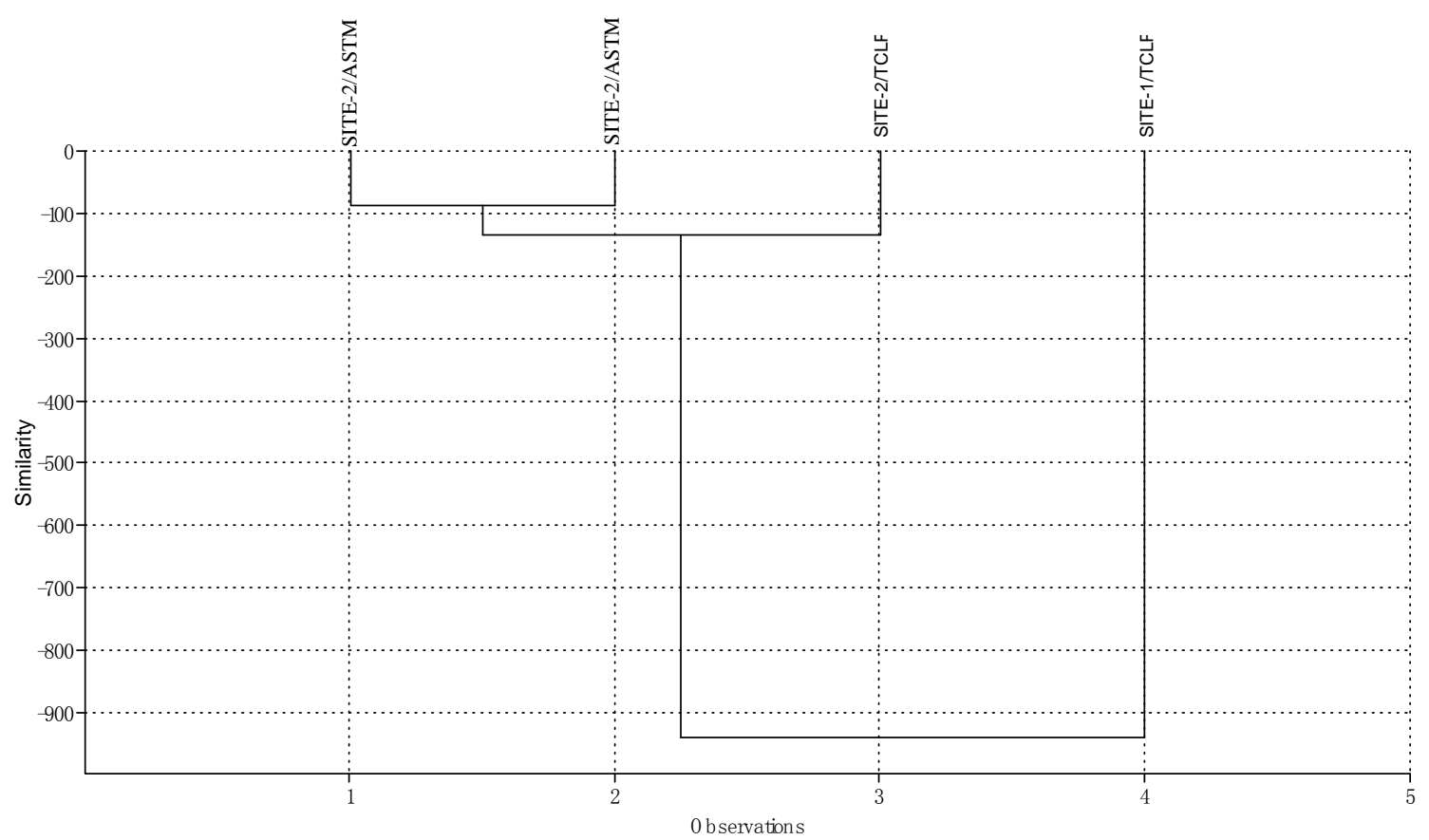

Figure 2. Cluster analysis dendrogram for leachate metal data set.

Table 2. Pearson's correlation coefficient $(p=0.05)$ of leachate metal data.

\begin{tabular}{ccccccc}
\hline & $\mathrm{Pb}$ & $\mathrm{Cr}$ & $\mathrm{Cu}$ & $\mathrm{Co}$ & $\mathrm{Cd}$ & \\
\hline $\mathrm{Pb}$ & 1 & & & & & \\
$\mathrm{Cr}$ & 0.805 & 1 & & & & \\
$\mathrm{Cu}$ & 0.981 & 0.895 & 1 & 1 & 1 & \\
$\mathrm{Co}$ & 0.759 & 0.995 & 0.865 & 0.868 & 0.968 & 1 \\
$\mathrm{Cd}$ & 0.902 & 0.869 & 0.956 & 0.963 & & \\
$\mathrm{Ni}$ & 0.880 & 0.966 & 0.955 & & & \\
\hline
\end{tabular}


Table 3. Comparison of variability: ASTM vs. US-EPA.

\begin{tabular}{|c|c|c|c|c|c|c|c|c|c|c|c|c|}
\hline \multirow{3}{*}{ Parameter } & \multicolumn{6}{|c|}{ SITE-1 } & \multicolumn{6}{|c|}{ SITE-2 } \\
\hline & \multicolumn{2}{|c|}{ Mean \pm sd } & \multicolumn{2}{|c|}{ CV (\%) } & \multicolumn{2}{|c|}{$90 \%$ UCL } & \multicolumn{2}{|c|}{ Mean \pm sd } & \multicolumn{2}{|c|}{ CV (\%) } & \multicolumn{2}{|c|}{$90 \%$ UCL } \\
\hline & ASTM & TCLP & ASTM & TCLP & ASTM & TCLP & ASTM & TCLP & ASTM & TCLP & ASTM & TCLP \\
\hline $\mathrm{pH}$ & $7.2 \pm 0.2$ & $4.9 \pm 1.6$ & 3 & 33 & - & - & $7.7 \pm 0.9$ & $5.0 \pm 0.4$ & 12 & 8 & - & - \\
\hline Lead & $27 \pm 26$ & $2250 \pm 3400$ & 96 & 151 & 55 & 5952 & $201 \pm 200$ & $32 \pm 51$ & 100 & 159 & 419 & 87 \\
\hline Chromium & $28 \pm 30$ & $323 \pm 110$ & 107 & 34 & 61 & 443 & $1.7 \pm 2.8$ & $190 \pm 86$ & 165 & 45 & 4.7 & 284 \\
\hline Copper & $152 \pm 200$ & $848 \pm 520$ & 132 & 61 & 370 & 1414 & $232 \pm 83$ & $296 \pm 99$ & 36 & 33 & 322 & 404 \\
\hline Cobalt & $18.0 \pm 6.6$ & $148 \pm 50$ & 33 & 34 & 25 & 202 & $16.3 \pm 7.6$ & $103 \pm 66$ & 50 & 64 & 25 & 175 \\
\hline Cadmium & $13 \pm 13$ & $104 \pm 39$ & 100 & 38 & 27 & 146 & $46 \pm 16$ & $51.7 \pm 30$ & 35 & 58 & 63 & 84 \\
\hline Nickel & $39 \pm 12$ & $538 \pm 230$ & 31 & 44 & 52 & 788 & $123 \pm 46$ & $283 \pm 150$ & 37 & 53 & 173 & 446 \\
\hline
\end{tabular}

CV: coefficient of variation, UCL: upper confidence limit. $(n=3)$; All mean values except $\mathrm{pH}$ in $\mu \mathrm{g} / \mathrm{L}$.

Proper and frequent monitoring of the sites is necessary to avoid extensive contamination.

\section{REFERENCES}

[1] T. H. Christensen, P. Kjeldsen, P. L. Bjerg, D. L. Jensen, J. B. Christensen and A. Baun, "Biogeochemistry of Landfill Leachate Plumes,” Applied Geochemistry, Vol. 16, No. 7-8, 2001, pp. 659-718. doi:10.1016/S0883-2927(00)00082-2

[2] D. Fatta, A. Papadopoulos and M. Loizidou, “A Study on the Landfill Leachate and Its Impact on the Groundwater Quality of the Greater Area,” Environmental Geochemistry and Health, Vol. 21, No. 2, 1999, pp. 175-190. doi:10.1023/A:1006613530137

[3] United States Environmental Protection Agency (USE PA), Office of Drinking Water, "A Ground Water Protection Strategy for the Environmental Protection Agency,” United State Government Printing Office, Washington DC, 1984, p. 64.

[4] J. Saarela, "Pilot Investigations of Surface Parts of Three Closed Landfills and Factors Affecting Them," Environmental Monitoring and Assessment, Vol. 84, No. 1-2, 2003, pp. 183-192. doi:10.1023/A:1022859718865

[5] H. Moo-Young, B. Johnson, A. Johnson, D. Carson, C. Lew, S. Liu and K. Hancock, "Characterization of Infiltration Rates from Landfills: Supporting Groundwater Modeling Efforts," Environmental Monitoring and Assessment, Vol. 96, No. 1-3, 2004, pp. 283-311. doi:10.1023/B:EMAS.0000031734.67778.d7

[6] S. C. Stark, I. Snape, N. J. Graham, J. C. Brennan and D. B. Gore, "Assessment of Metal Concentration Using XRay Fluorescence Spectrometry and the Toxicity Characteristic Leaching Procedure (TCLP) during Remediation of a Waste Disposal Site in Antarctica," Journal of Environmental Monitoring, Vol. 10, No. 1, 2008, pp. 60-70. doi:10.1039/b712631j

[7] A. O. Aderemi, A. V. Oriaku, G. A. Adewumi and A. A. Otitoloju, "Assessment of Groundwater Contamination by Leachate near a Municipal Solid Waste Landfill,” African Journal of Environmental Science and Technology, Vol. 5, No. 11, 2011, pp. 933-940.

[8] S. Mor, K. Ravindra, R. P. Dahiya and A. Chandra, "Leachate Characterization and Assessment of Groundwater Pollution near Municipal Solid Waste Landfill Site," Environmental Monitoring and Assessment, Vol. 4, 2006, pp. 325-334.

[9] T. Timothy, J. Youg-Chul and T. Thabet, “A Guide to the Use of Leaching Test in Solid Waste Management Decision Making,” Report \#03-01(A), The Florida Center for Solid and Hazardous Waste Management, Gainesville, 2003, pp. 12-37.

[10] R. S. Al-Abed, L. Philip, G. Hageman, N. M. Jegadeesan and A. Derrick, "Comparative Evaluation of Short-Term Leach Test for Heavy Metal Release from Mineral Processing Waste," Science of the Total Environment, Vol. 364, No. 1-3, 2006, pp. 14-23. doi:10.1016/j.scitotenv.2005.10.021

[11] United State Environmental Protection Agency (USEPA), "Test Methods for Evaluating Solid Waste-Physical Chemical Methods SW-846,” Environmental Protection Agency, Washington DC, 1997, p. 173.

[12] L. P. Carry, R. K. Jean and A. W. Donald, "The Use of Extraction Test for Deciding Waste Disposal Options," Trend in Analytical Chemistry, Vol. 1, No. 14, 1982, pp. 342-347. doi:10.1016/0165-9936(82)80101-5

[13] N. W. Hanson, "Official Standard and Recommended Methods of Analysis,” The Society for Analytical Chemistry, London, 1973, p. 79.

[14] APHA-AWWA-WPCF, "Standard Methods for the Examination of Water and Wastewater," American Public Health Association, Washington DC, 1994.

[15] United State Environmental Protection Agency (US-EPA), "Test Methods for Evaluating Solid Waste USEPA SW846," United State Government Printing Office, Washington DC, 1996, p. 231. 